Research Article

\title{
Bioactive Characteristics of Wild Berberis vulgaris and Berberis crataegina Fruits
}

\author{
Arzu Yaşar Eroğlu, ${ }^{1}$ Özlem Çakır $\mathbb{D}^{1},{ }^{1}$ Mustafa Sağdıç, ${ }^{2}$ and Enes Dertli ${ }^{3}$ \\ ${ }^{1}$ Department of Food Engineering, Faculty of Engineering, Bayburt University, Dedekorkut Campus, Bayburt 69000, Turkey \\ ${ }^{2}$ Department of Elementary Education, Faculty of Education, Yildiz Technical University, Davutpasa Campus, Esenler, \\ Istanbul 34210, Turkey \\ ${ }^{3}$ Department of Food Engineering, Faculty of Chemical and Metallurgical Engineering, Yildiz Technical University, \\ Davutpasa Campus, Esenler, Istanbul 34210, Turkey
}

Correspondence should be addressed to Özlem Çakır; ocakir@bayburt.edu.tr

Received 17 April 2020; Accepted 5 June 2020; Published 24 June 2020

Academic Editor: Jorge Barros-Velázquez

Copyright ( $) 2020$ Arzu Yaşar Eroğlu et al. This is an open access article distributed under the Creative Commons Attribution License, which permits unrestricted use, distribution, and reproduction in any medium, provided the original work is properly cited.

\begin{abstract}
There is an increasing trend to find novel sources of products with high antioxidant capacity and wild fruits are very good examples for these sources. In this study, fruits of Berberis vulgaris and Berberis crataegina, naturally grown in Bayburt province of Turkey, were tested for their physicochemical features, antioxidant capacities, phenolic compound profiles, and antimicrobial activities. The physicochemical analysis of the fruits revealed that the dry matter content, ash content, $\mathrm{pH}$, and $a_{\mathrm{w}}$ values were between $28.47 \%$ and $41.61 \%, 0.65 \%$ and $2.13 \%, 2.44$ and 3.25 , and 0.996 and 0.97 , respectively. The total phenolic content of the fruits was determined by the Folin-Ciocalteu methodology, and for the determination of the antioxidant capacity of the fruits, $\mathrm{DPPH}, \mathrm{ABTS}$, and $\beta$-carotene bleaching methods were performed and a high level of antioxidant activity was observed. HPLC analysis was applied to identify the phenolic content of the fruits, and gallic acid and chlorogenic acid were found to be the dominant phenolic compounds in Berberis fruits. The water extracts of the Berberis fruits were tested against important foodborne pathogenic bacteria as potential antimicrobials. The extracts inhibited the growth of Bacillus cereus, Salmonella typhimurium, Yersinia enterocolitica, and Staphylococcus aureus at significant rates. This study revealed the potential antioxidant and antimicrobial characteristics of wild-type B. vulgaris and B. crataegina that can be used for different future applications.
\end{abstract}

\section{Introduction}

There is an increasing demand for different sources for food production and nutritious wild fruits are very suitable sources for food industry [1]. Due to this and many other advantageous features, scientific studies on the nutritional content and medicinal values of different wild edible fruits grown in various parts of the world are of great interest [2]. These types of fruits are also among the important food sources due to their antioxidant capacity and they might also have antimicrobial features. Berberidaceae family consists of the most important natural wild fruits, and they comprise about 14 genera and 700 species [3]. Berberis is one of the genera of this family.
The Berberis genus has about 500 species in the world [4]. Wild barberry is found in nature on stony soils and between forest openings or bushes at altitudes of 500-1500 m. There are four types of Berberis species naturally grown in Turkey, which are B. vulgaris L., B. crataegina DC., B. cretica L., and $B$. integerrima B. From these species, B. vulgaris L. and $B$. crataegina DC. were selected for further studies in this study. B. vulgaris L. are generally grown in the northern Anatolia provinces such as Kastamonu and Tokat as well as along Çoruh and Kelkit valleys alongside the Black Sea regions [5]. The yellow bunch of flowers that blossom in April or May consist of 15-25 flowers. Its fruits are 8-12 mm tall with an elliptical structure, turning into a beautiful red color when they ripen. The fruit is the most used organ of this plant in 
traditional and modern medicine [6]. For medical purposes, studies have been conducted on the fruits and roots of $B$. vulgaris. Berberine is extracted as an alkaloid from the roots and bark of B. vulgaris [7]. Fruit extracts from B. vulgaris L. possess various beneficial properties, which are beneficial in both cardiovascular and nervous systems, thus presenting a potential use in the treatment of some neuronal disorders such as hypertension, epilepsy, and contraction [8, 9]. $B$. crataegina DC. can possibly grow in small and large group bushes located between the arid and rocky slopes at altitudes of $800-1500 \mathrm{~m}$. In some occasions, the fruits are found individually, while in others they appear in the form of a bunch of grapes. Their taste is slightly sour. The B. crataegina fruits contain tannins, organic acids, high levels of vitamin $\mathrm{C}$, and anthocyanins [10]. It is stated that the berberine alkaloid and extracts obtained from the B. crataegina DC. plant have a strong antifungal activity [11].

In this study, fruits of $B$. vulgaris L. and B. crataegina DC. were collected from Bayburt province of Turkey, and the physicochemical characteristics, antioxidant capacities, phenolic substance profiles, and antimicrobial activities of the fruit extracts were determined. General appearances of $B$. vulgaris $\mathrm{L}$. and $B$. crataegina DC. are presented in Figures 1(a) and 1(b), respectively.

The physicochemical characteristics of the wild fruits were determined in terms of dry matter content, watersoluble dry matter content, $\mathrm{pH}$, water activity $\left(a_{\mathrm{w}}\right)$, and ash content. The antioxidant capacities of the fruits were determined using DPPH, ABTS, and $\beta$-carotene bleaching methods and total phenolic content of the fruits was determined by the Folin-Ciocalteu methodology. High-performance liquid chromatography (HPLC) analysis was applied to determine the phenolic compounds presented in the tested fruits. Finally, the antimicrobial activity of the water extracts of the Berberis fruits were tested against foodborne pathogenic bacteria including Bacillus cereus, Salmonella typhimurium, Yersinia enterocolitica, and Staphylococcus aureus.

\section{Materials and Methods}

2.1. Collection of Wild Fruits. B. vulgaris L. and B. crataegina DC. fruits collected from 11 different regions of Bayburt geographical regions (Turkey) were identified botanically at the Food Engineering Department of Bayburt University (Turkey). The fruits were kept in suitable containers, brought to the laboratory, and stored at $-80^{\circ} \mathrm{C}$ until further analysis. Photographs of Berberis fruits tested in this study are presented in Figure 2.

2.2. Determination of Physicochemical Properties of Berberis Fruits. For the dry matter analysis, $3 \mathrm{~g}$ of fruit sample was weighed and dried at $105^{\circ} \mathrm{C}$ and the dry matter content (\%) was determined by comparison of dry weight/fresh weight. To determine the water-soluble dry matter content, the fruit pulps were filtered through cheesecloth and dropped into the prism of the Abbe refractometer (Model Ra 250HE, Kyoto Electronics Manufacturing Co., Ltd., Japan) and the amounts of water-soluble dry matter at $20^{\circ} \mathrm{C}$ were recorded. To determine the ash content of the fruits, samples were placed to an ash oven at $500^{\circ} \mathrm{C}$, and the burning process continued until a light gray-white color formed in the samples. The weight of the samples was calculated following the burning process and the ash content \% was determined. The $\mathrm{pH}$ values of the fruits were measured with $\mathrm{pH}$ meter (Jenco Electronics, 6173 brand) from the fruit juice obtained by crushing the fruits in porcelain mortar. The water activity $\left(a_{\mathrm{w}}\right)$ of the homogenized fruit samples was determined with the temperature-controlled Aqua Lab brand (Decagon Devices, Inc., Pullman, WA) water activity device.

2.3. Preparation of Fruit Extracts. For the determination of the antioxidant activity of the Berberis fruits, the extraction process of Meng et al. [12] was applied with slight modifications. Briefly, at first, drying of fruits was conducted at $55^{\circ} \mathrm{C}$ for 3 days. Dried fruits were slightly crushed in mortar and $3 \mathrm{~g}$ from the slightly crushed fruits was weighed. Both water and ethanol-water $(80: 20)$ extracts were prepared for the antioxidant activity (Table 1 ) by adding $30 \mathrm{ml}$ of distilled water and ethanol:water $(80: 20)$ to $3 \mathrm{~g}$ fruits and solutions were left in shaker for 15 hours. At the end of the period, samples were moved into centrifuge tubes and centrifuged at $5000 \mathrm{rpm}$ for 15 minutes at $4^{\circ} \mathrm{C}$. The centrifuged samples were filtered through $110 \mathrm{~mm}$ filter papers. Fruit extracts obtained after extraction were stored in separate tubes at $-20^{\circ} \mathrm{C}$ until use.

2.4. Determination of Antioxidant Characteristics of Berberis Fruits. The total phenolic content, antioxidant activity (DPPH •, $\beta$-carotene bleaching, and ABTS • +), and phenolic compositions of the fruit extracts were determined. Table 1 shows the identification used in the display for the ease of writing of fruits extracted with ethanol or water in terms of location and variety. The $\beta$-carotene bleaching method to test the total antioxidant activities of fruit samples in the extract obtained with ethanol: water $(80: 20)$ and water was applied as described previously [13]. Butylated hydroxyanisole (BHA) was used as the standard substance. The degradation rate (DR) was calculated according to firstorder kinetics using the following equation:

$$
\text { DR sample; control; standard }=\ln \left(\frac{a}{b}\right) \times \frac{1}{t},
$$

where $\ln$ is natural log, $a$ is the initial absorbance $(470 \mathrm{~nm})$ at time $0, b$ is the absorbance $(470 \mathrm{~nm}$ ) at $100 \mathrm{~min}$, and $t$ is time.

The antioxidant activity (AA) was expressed as percent of inhibition relative to the control, using the following formula:

$$
\mathrm{AA}=\frac{(\mathrm{DR} \text { control }- \text { DR sample or standard })}{\text { DR control } \times 100} .
$$

$\mathrm{DPPH}$ - radical scavenging activity was performed according to Gülçin [14]. The absorbance of the samples was recorded at $517 \mathrm{~nm}$. The reduced absorbance value gives the remaining DPPH solution or the free radical scavenging activity. 


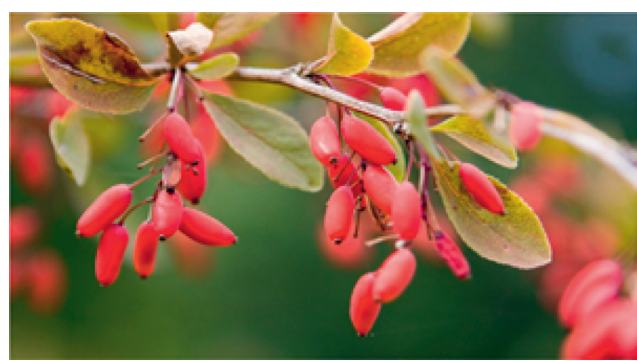

(a)

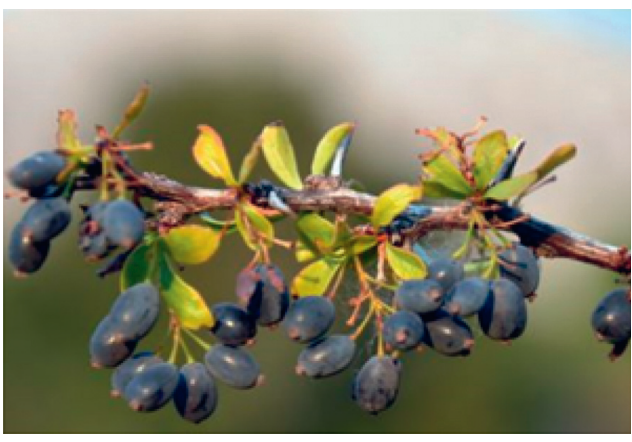

(b)

FIgURE 1: Fruits of Berberis vulgaris L. (a) and Berberis crataegina DC. (b).
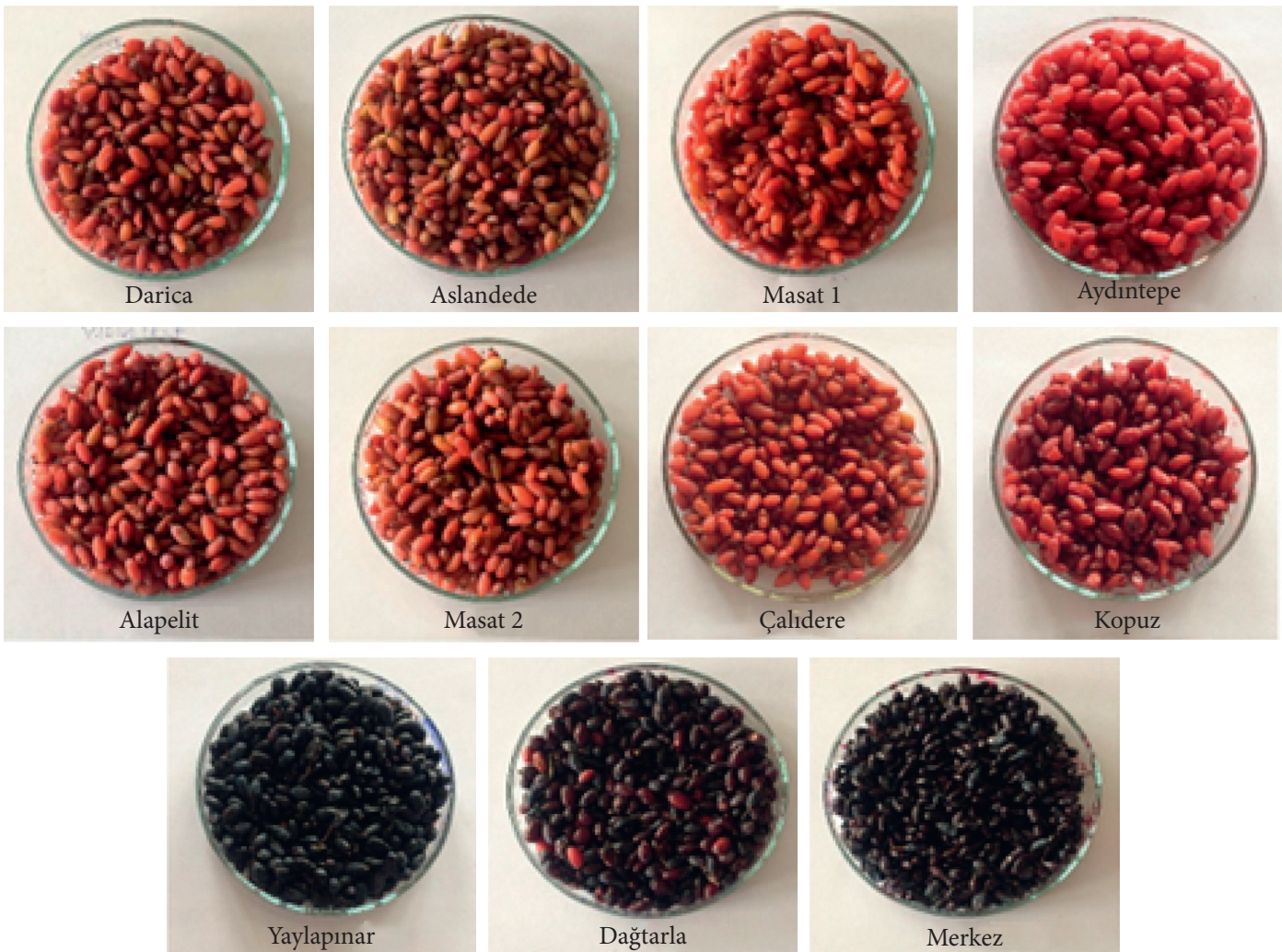

Figure 2: Berberis vulgaris L. and Berberis crataegina DC. samples used in the research.

For ABTS •+ analysis, the method described by Huang et al. [15] was slightly modified and applied. Briefly, $0.008 \mathrm{~g}$ of ABTS was dissolved in distilled water and mixed with $13.2 \mathrm{mg}$ of potassium persulfate to obtain the dark blue solution following 16 hours of incubation. This solution was diluted with ethanol to obtain OD $734 \mathrm{~nm}$ of 0.7 and then $100 \mu \mathrm{l}$ sample was mixed with $2.4 \mathrm{ml} \mathrm{ABTS} \bullet+$ solution and kept at room temperature for 6 minutes; then its absorbance was recorded. In DPPH and ABTS methods, the dilution of each extract $(6.67 \mathrm{mg} / \mathrm{ml})$ was prepared in ethanol/water $(\mathrm{v} / \mathrm{v})$ and the $\%$ inhibition values were calculated according to the following equation:

$$
\text { inhibition } \%=\frac{\left[\left(A_{\mathrm{DPPH} \text { or ABTS }}-A_{\text {extract }}\right)\right]}{A_{\mathrm{DPPH} \text { or ABTS }}} \times 100 \text {. }
$$

2.5. Determination of the Total Phenolic Content of Fruits. The Folin-Ciocalteu (FC) methodology was applied to determine the total phenolic content of the fruit extracts using the method described by Gülçin et al. [16]. Briefly, $1 \mathrm{ml}$ taken from the prepared extracts was mixed with $5 \mathrm{ml}$ FC reagent (1:10). After placing for 3 minutes at room temperature, $4 \mathrm{ml}$ of $7.5 \% \mathrm{Na}_{2} \mathrm{CO}_{3}$ solution was added and the absorbance 
TABle 1: Location, variety, and codes of the fruits used in the research.

\begin{tabular}{|c|c|c|c|}
\hline \multirow{2}{*}{ Collected regions } & \multirow{2}{*}{ Variety } & \multicolumn{2}{|c|}{ Codes of the extracts } \\
\hline & & Ethanolic & Water \\
\hline Darıca village & Berberis vulgaris $\mathrm{L}$. & Bv-EtOH-1 & $\mathrm{Bv}-\mathrm{W}-1$ \\
\hline Aslandede village & Berberis vulgaris $\mathrm{L}$. & $\mathrm{Bv}-\mathrm{EtOH}-2$ & BvW2 \\
\hline Masat village 1 & Berberis vulgaris $\mathrm{L}$. & Bv-EtOH-3 & $\mathrm{Bv}-\mathrm{W}-3$ \\
\hline Aydıntepe district & Berberis vulgaris $\mathrm{L}$. & Bv-EtOH-4 & $\mathrm{Bv}-\mathrm{W}-4$ \\
\hline Alapelit village & Berberis vulgaris $\mathrm{L}$. & Bv-EtOH-5 & Bv-W-5 \\
\hline Masat village 2 & Berberis vulgaris $\mathrm{L}$. & Bv-EtOH-6 & $\mathrm{Bv}-\mathrm{W}-6$ \\
\hline Çalıdere village & Berberis vulgaris $\mathrm{L}$. & Bv-EtOH-7 & $\mathrm{Bv}-\mathrm{W}-7$ \\
\hline Kopuz village & Berberis vulgaris $\mathrm{L}$. & Bv-EtOH-8 & $\mathrm{Bv}-\mathrm{W}-8$ \\
\hline Yayla & $\begin{array}{c}\text { Berberis crataegina } \\
\text { DC. }\end{array}$ & Bc-EtOH-9 & $\mathrm{Bc}$ \\
\hline Dağtarla village & $\begin{array}{c}\text { Berberis crataegina } \\
\text { DC. }\end{array}$ & $\begin{array}{c}\text { Bc-EtOH- } \\
10\end{array}$ & $\begin{array}{c}\mathrm{Bc}-\mathrm{W}- \\
10\end{array}$ \\
\hline $\begin{array}{l}\text { Bayburt city } \\
\text { center }\end{array}$ & $\begin{array}{c}\text { Berberis crataegina } \\
\text { DC. }\end{array}$ & $\begin{array}{c}\text { Bc-EtOH- } \\
11\end{array}$ & $\begin{array}{c}\mathrm{Bc}-\mathrm{W}- \\
11\end{array}$ \\
\hline
\end{tabular}

was recorded at $760 \mathrm{~nm}$ after incubation in the dark for 90 minutes at room temperature. Calibration curves were generated using gallic acid as standard and the results were presented as gallic acid equivalent (microgram GAE/mg sample).

2.6. Determination of Phenolic Compounds. The phenolic content of the fruit extracts was determined by HPLC analysis using a Photodiode Array Detector (PDA) attached to Shimadzu SPP-M20A HPLC system [17]. Samples were passed through $0.45 \mu \mathrm{m}$ membrane filter and transferred to HPLC vials at $100 \mu \mathrm{l}$ volume. An Inertsil ODS-3, $5 \mu \mathrm{m}$, $(25 \times 4.6 \mathrm{~mm})$ column was used with mobile phase of gradient system of methanol (A) and water $+2 \%$ acetic acid (B) with a column temperature of $30^{\circ} \mathrm{C}$. The phenolic compound was detected at $254 \mathrm{~nm}$ (in the range of $210-360 \mathrm{~nm}$ ). Standards included in the analysis were gallic acid, 4hydroxybenzoic acid, chlorogenic acid, vanillic acid, caffeic acid, syringic acid, $p$-coumaric acid, trans-ferulic acid, and sinapic acid.

2.7. Antimicrobial Activity of Water Extracts of Wild Fruit Extracts. For the antimicrobial activity tests, pathogenic strains Escherichia coli BC 1402, Bacillus cereus BC 6830, Salmonella typhimurium RSSK 95091, Yersinia enterocolitica ATCC 27729, and Staphylococcus aureus ATCC 25923 were grown in Tryptic Soy Broth (TSB) at $37^{\circ} \mathrm{C}$ aerobically. From the overnight grown bacterial cells, pathogenic strains were spread to the TSB gar plates and $20 \mu \mathrm{l}$ of the water extracts of Berberis fruits was applied to these agar plates which were then incubated at $37^{\circ} \mathrm{C}$ for $24 \mathrm{~h}$. Following the incubation, the inhibition zones formed due to the antimicrobial activities of the water extracts were recorded and expressed as diameters for the inhibition zone.

2.8. Statistical Analysis. In all of the data obtained, the mean values of physicochemical and biochemical parameters were compared using one-way analysis of variance (ANOVA). All data were determined as mean value \pm standard deviation; $p<0.05$ was considered as statistically significant.

\section{Results and Discussion}

3.1. Physicochemical Characteristics of Berberis Fruits. In this study, fruits of $B$. vulgaris $\mathrm{L}$. and B. crataegina DC. were collected from eleven different regions of Bayburt province to determine their potential technofunctional characteristics. The physicochemical properties of these fruits were determined at first in terms of dry matter content, watersoluble dry matter content, $\mathrm{pH}, a_{\mathrm{w}}$, and ash content. Table 2 shows the physicochemical characteristics of these wild fruits. The amount of dry matter content is an important criterion in terms of the determination of the consumption status of the fruits [18]. The amount of dry matter in the collected Berberis fruits varied between 28.47\% and 41.61\% (Table 2). The results obtained in this study from Berberis fruits were similar to those reported by Demir [19] and Karabulut [20]. It was determined as $31.22 \pm 1.177 \%$ in $B$. vulgaris by Demir [19] and as $9.03 \pm 0.27 \%$ in $B$. vulgaris and $32.77 \pm 2.43 \%$ in B. crataegina by Karabulut [20]. The lowest dry matter was determined from the Berberis fruits grown in Alapelit village with $28.47 \%$, and the highest was from the central district with $41.61 \%$. Significant levels of differences were observed among the fruits $(p<0.05)$ in terms of dry matter content.

The ash content of Berberis fruits was determined to be between $0.65 \%$ and $2.13 \%$ (Table 2). Previous reports demonstrated the ash content of $B$. vulgaris samples between $0.65 \%$ and $3.44 \%[19,21,22]$ and $1.36 \pm 0.07 \%$ for $B$. crataegina [20]. On the other hand, the data we obtained was parallel to that of Akbulut et al. [21] and Karabulut [20], but was lower than that of Demir [19], and was higher than that of Yildiz et al. [22]. It can be suggested that these differences in the amount of ash content may result from the growing conditions of the fruits. There was a significant level of difference $(p<0.05)$ in terms of ash content among the fruit samples (Table 2). The $\mathrm{pH}$ value of the Berberis fruits was in the range of 2.44-3.25. In previous studies, the $\mathrm{pH}$ values of Berberis fruits were determined to be 5.5 by Demir [19], 3.35 by Akbulut et al. [21], between 3.13 and 4.43 by Ahmed et al. [23], 3.06 by Ardestani et al. [24], between 2.68 and 3.26 by Yildiz et al. [22], and between 2.59 and 3.2 by Okatan and Colak [25]. And finally, Karabulut [20] determined the $\mathrm{pH}$ values as $2.85 \pm 0.16$ and $3.05 \pm 0.01$ in B. vulgaris and B. crataegina, respectively. Our results were in a similar range compared to the previous studies. The lowest $\mathrm{pH}$ value was determined in Berberis fruit grown in Aydintepe as 2.44 and the highest was in Yaylapinar as 3.25.

The $a_{\mathrm{w}}$ values of the Berberis fruits were in the range of 0.931-0.947. Karabulut [20] reported the $a_{\mathrm{w}}$ value as 0.95 in $B$. vulgaris and 0.94 in $B$. crataegina which was higher compared to our findings. The lowest water activity value was obtained from the Berberis fruits collected from the central district and Yaylapinar village as 0.931, whereas the highest was obtained from the Aslandede village as 0.947 (Table 2). 
TABle 2: Physicochemical properties of Berberis fruits collected from Bayburt province.

\begin{tabular}{|c|c|c|c|c|c|}
\hline Collected regions & Dry matter (DM) \% & Water-soluble DM (\%) & Ash (\%) & $a_{\mathrm{w}}$ & $\mathrm{pH}$ \\
\hline Darıca & $29.89 \pm 2.18^{\mathrm{cd} *}$ & $19.25 \pm 0.77^{\mathrm{a}}$ & $0.84 \pm 0.02^{\mathrm{gh}}$ & $0.938 \pm 0.000^{\mathrm{bc}}$ & $2.76 \pm 0.02^{b}$ \\
\hline Aslandede & $29.34 \pm 0.34^{\mathrm{cd}}$ & $18.10 \pm 1.41^{\mathrm{a}}$ & $0.68 \pm 0.04^{\mathrm{h}}$ & $0.947 \pm 0.002^{\mathrm{a}}$ & $2.84 \pm 0.30^{\mathrm{ab}}$ \\
\hline Masat 1 & $30.20 \pm 1.21^{\mathrm{cd}}$ & $19.55 \pm 2.33^{\mathrm{a}}$ & $0.99 \pm 0.05^{\mathrm{fg}}$ & $0.945 \pm 0.001^{\mathrm{a}}$ & $2.73 \pm 0.03^{b}$ \\
\hline Aydintepe & $28.49 \pm 3.27^{\mathrm{d}}$ & $19.20 \pm 0.14^{\mathrm{a}}$ & $0.76 \pm 0.05^{\mathrm{h}}$ & $0.942 \pm 0.001^{\mathrm{abc}}$ & $2.44 \pm 0.04^{\mathrm{b}}$ \\
\hline Alapelit & $28.47 \pm 0.67^{\mathrm{d}}$ & $20.40 \pm 0.70^{\mathrm{a}}$ & $1.45 \pm 0.02^{\mathrm{cd}}$ & $0.946 \pm 0.002^{\mathrm{a}}$ & $2.80 \pm 0.14^{\mathrm{ab}}$ \\
\hline Masat 2 & $31.17 \pm 0.71^{\mathrm{cd}}$ & $18.60 \pm 2.40^{\mathrm{a}}$ & $0.65 \pm 0.06^{\mathrm{h}}$ & $0.944 \pm 0.000^{\mathrm{a}}$ & $2.66 \pm 0.04^{\mathrm{b}}$ \\
\hline Çalıdere & $34.55 \pm 0.26^{\mathrm{bc}}$ & $20.85 \pm 5.02^{\mathrm{a}}$ & $1.68 \pm 0.02^{\mathrm{b}}$ & $0.938 \pm 0.001^{\mathrm{bc}}$ & $2.87 \pm 0.11^{\mathrm{ab}}$ \\
\hline Kopuz & $29.27 \pm 0.43^{\mathrm{cd}}$ & $18.85 \pm 0.49^{\mathrm{a}}$ & $1.08 \pm 0.01^{\mathrm{ef}}$ & $0.943 \pm 0.002^{\mathrm{ab}}$ & $2.64 \pm 0.04^{\mathrm{b}}$ \\
\hline Yaylapınar & $39.59 \pm 1.12^{\mathrm{ab}}$ & $26.30 \pm 0.14^{\mathrm{a}}$ & $1.52 \pm 0.10^{\mathrm{bc}}$ & $0.931 \pm 0.000^{\mathrm{de}}$ & $3.25 \pm 0.02^{\mathrm{a}}$ \\
\hline Dağtarla & $34.71 \pm 0.66^{\mathrm{bc}}$ & $23.00 \pm 0.00^{\mathrm{a}}$ & $1.27 \pm 0.02^{\mathrm{de}}$ & $0.937 \pm 0.000^{\mathrm{cd}}$ & $2.74 \pm 0.11^{\mathrm{b}}$ \\
\hline Bayburt city center & $41.61 \pm 1.88^{\mathrm{a}}$ & $27.75 \pm 6.01^{\mathrm{a}}$ & $2.13 \pm 0.02^{\mathrm{a}}$ & $0.931 \pm 0.001^{\mathrm{e}}$ & $3.23 \pm 0.04^{\mathrm{a}}$ \\
\hline
\end{tabular}

*Different superscript letters show the differences between the samples $(p<0.05$ significance level).

The water-soluble dry matter content of the Berberis fruits was found to be between $18.10 \%$ and $27.75 \%$ (Table 2). For B. vulgaris samples, the water-soluble dry matter content was reported to be between 16.93 and $23 \%$ [7, 20, 22, 24-26], whereas for $B$. crataegina a water-soluble dry matter content of $29.5 \%$ was reported in the literature [20]. The lowest water-soluble dry matter content was detected in Berberis fruit grown in Aslandede village as $18.10 \%$, whereas the highest value was found in Berberis fruit grown in the central district as $\mathbf{2 7 . 7 5 \%}$ value. No statistical significant difference was found in water-soluble dry matter content of the Berberis fruits $(p>0.05)$.

3.2. Total Phenolic Content and Antioxidant Activity of Berberis Fruits. One of the main reasons to explore the technofunctional properties of wild fruits is that they might have important levels of antioxidant activity originating from the phenolic substances presenting in the fruits. In this respect, the total phenolic content of the Berberis fruits was determined as $\mu \mathrm{g} \cdot \mathrm{GAE} \cdot \mathrm{mg} \cdot \mathrm{DM}^{-1}$ and the antioxidant capacity of these fruits was tested with $\beta$-carotene, $\mathrm{DPPH}^{\bullet}$, and $\mathrm{ABTS}^{\bullet}{ }^{+}$methodologies. Table 3 shows the total phenolic content and antioxidant characteristics of water and ethanol extracts of Berberis fruits. The total phenolic content of the samples was observed to be within the range of $148.0-448.3 \mu \mathrm{g}$.GAE.mg. $\mathrm{DM}^{-1}$ with the lowest and highest levels observed in Bv-W-8 (water extract) and Bv-EtOH-5 (ethanol extract) samples, respectively (Table 3). Previous studies also revealed the phenolic content of Berberis fruits, and our findings were lower $[7,22,26,27]$ or higher [20] compared to different reports showing the importance of the origin of the samples that can be affected by the geographical conditions. We should also note that there was significant difference among the samples collected from different regions of Bayburt province $(p<0.05)$.

The first methodology that was used for the determination of the antioxidant characteristics of Berberis fruits was $\beta$-carotene bleaching method. As can be seen in Table 3 , the antioxidant levels of Berberis fruits were observed to be between $62.83 \%$ and $92.19 \%$. The antioxidant capacity of the ethanol extracts was within the similar range compared to the BHA used as standard in $\beta$-carotene bleaching method (96.22\% antioxidant activity). Our findings were similar to the previous observations as Motalleb et al. [27] determined the antioxidant activity of $B$. vulgaris fruits by $\beta$-carotene bleaching method as $73.62 \%$ in ethanol extract and $82.52 \%$ in water extract. Yildiz et al. [22] found $75.01-90.64 \%$ antioxidant activity in B. vulgaris, whereas Karabulut [20] found $87.35 \%$ and $90.50 \%$ antioxidant activity for B. vulgaris and B. crataegina, respectively. The lowest and the highest antioxidant activity with $\beta$-carotene bleaching method were observed in Bc-W-11 as $62.83 \%$ and in Bv-EtOH-5 as 92.19\%, respectively (Table 3 ).

Another test used to determine the antioxidant activity of the Berberis fruits was DPPH radical scavenging activity test and the antioxidant level of the Berberis fruits was observed to be in the range of $11.92 \%-40.44 \%$ (Table 3). Previously, Motalleb et al. [27] determined the B. vulgaris $\mathrm{DPPH} \bullet$ free radical cleaning activity as $82.52 \pm 0.64 \%$ and $73.62 \pm 1.87 \%$ for water and ethanol extracts, respectively. Karabulut [20] reported the antioxidant content as $15.65 \mathrm{mg} \mathrm{ml}^{-1}$ in B. vulgaris and $6.30 \mathrm{IC}_{50} \mathrm{mg} \cdot \mathrm{ml}^{-1}$ in $B$. crataegina, while Gholizadeh-Moghadam et al. [28] found the highest antioxidant activity in B. vulgaris as $56.84 \%$. The radical scavenging activity of $\mathrm{Bc}-\mathrm{EtOH}-11$ extract was the lowest with $11.92 \%$, and the radical scavenging activity of $\mathrm{Bv}-\mathrm{W}-7$ extract was the highest with $40.44 \%$.

Finally, we used $\mathrm{ABTS}^{\bullet+}$ methods to determine the antioxidant characteristics of Berberis fruits (Table 3). Previously, the antioxidant capacity of $B$. vulgaris was tested and Özgen et al. [7] determined the ABTS $^{\bullet+}$ antioxidant capacity between 41.1 and $49.3 \mathrm{TE}$ at $\mathrm{mmol} \cdot \mathrm{L}^{-1}$. Yildiz et al. [22] expressed the ABTS value for Trolox equivalent mole per liter of juice between 53.2 and $56.10 \mathrm{mmol}$ per L. Similar to the previous tests used in this study, $\mathrm{ABTS}^{\bullet+}$ radical cleaning activity of water extracts was found to be higher compared to the ethanol extracts. The lowest and the highest $\mathrm{ABTS}^{\bullet+}$ results were observed for sample Bv-EtOH-8 and sample Bc-W-9 with $33.06 \%$ and $92.85 \%$, respectively.

3.3. Determination of Phenolic Profiles of Berberis Fruits by HPLC Analysis. As Berberis fruits showed high level of antioxidant capacity, we then performed HPLC analysis to determine the presence and the level of phenolic compounds within these fruits and the levels of gallic acid, 4-hydroxybenzoic acid, chlorogenic acid, vanillic acid, caffeic acid, 
TABLE 3: Total phenolic content and antioxidant activities of Berberis fruits.

\begin{tabular}{|c|c|c|c|c|}
\hline Extracts & Total phenolic content $(-\mu \mathrm{g} \cdot \mathrm{GAE} / \mathrm{mg} \cdot \mathrm{DM})$ & $\beta$-Carotene (\%) & $\mathrm{DPPH}^{\bullet}(\%)$ & $\mathrm{ABTS}^{\bullet+}(\%)$ \\
\hline Bv-EtOH-1 & $316.0 \pm 58.8^{\mathrm{abcd}}$ & $73.64 \pm 0.90^{\text {efghr }}$ & $26.70 \pm 0.19^{\mathrm{de}}$ & $42.53 \pm 4.28^{\mathrm{ef}}$ \\
\hline $\mathrm{Bv}-\mathrm{W}-1$ & $195.0 \pm 38.2^{\mathrm{cd}}$ & $67.78 \pm 2.81^{\text {hij }}$ & $26.88 \pm 2.45^{\mathrm{de}}$ & $86.01 \pm 0.72^{\mathrm{ab}}$ \\
\hline Bv-EtOH-2 & $334.7 \pm 61.9^{\mathrm{abcd}}$ & $88.77 \pm 0.38^{\mathrm{ab}}$ & $26.98 \pm 0.19^{\mathrm{de}}$ & $57.77 \pm 3.84^{\text {bcdef }}$ \\
\hline $\mathrm{Bv}-\mathrm{W}-2$ & $163.4 \pm 32.9^{\mathrm{d}}$ & $70.25 \pm 2.60^{\text {ghij }}$ & $25.17 \pm 2.50^{\mathrm{ef}}$ & $76.52 \pm 0.82^{\text {abcde }}$ \\
\hline $\mathrm{Bv}-\mathrm{EtOH}-3$ & $440.2 \pm 79.9^{\mathrm{ab}}$ & $79.50 \pm 0.70^{\text {cdef }}$ & $26.53 \pm 0.19^{\text {de }}$ & $48.44 \pm 13.70^{\mathrm{def}}$ \\
\hline $\mathrm{Bv}-\mathrm{W}-3$ & $337.1 \pm 62.4^{\mathrm{abcd}}$ & $69.02 \pm 2.70^{\mathrm{hij}}$ & $27.92 \pm 2.42^{\text {bcde }}$ & $83.53 \pm 0.70^{\mathrm{abc}}$ \\
\hline $\mathrm{Bv}-\mathrm{EtOH}-4$ & $341.1 \pm 63.0^{\mathrm{abcd}}$ & $82.42 \pm 0.60^{\mathrm{bcd}}$ & $27.35 \pm 0.19^{\text {cde }}$ & $50.04 \pm 4.67^{\text {cdef }}$ \\
\hline $\mathrm{Bv}-\mathrm{W}-4$ & $307.9 \pm 57.4^{\mathrm{abcd}}$ & $80.91 \pm 1.66^{\mathrm{cde}}$ & $29.34 \pm 2.37^{\text {bcde }}$ & $83.10 \pm 0.53^{\mathrm{abc}}$ \\
\hline $\mathrm{Bv}-\mathrm{EtOH}-5$ & $448.3 \pm 81.2^{\mathrm{a}}$ & $92.19 \pm 0.26^{\mathrm{a}}$ & $33.46 \pm 0.17^{\mathrm{abcd}}$ & $34.3 \pm 20.0^{\mathrm{f}}$ \\
\hline Bv-W-5 & $355.8 \pm 65.5^{\mathrm{abcd}}$ & $72.73 \pm 2.38^{\text {fghr }}$ & $27.77 \pm 2.37^{\text {bcde }}$ & $80.40 \pm 12.45^{\mathrm{abcd}}$ \\
\hline $\mathrm{Bv}-\mathrm{EtOH}-6$ & $398.0 \pm 72.7^{\mathrm{abc}}$ & $89.26 \pm 0.36^{\mathrm{ab}}$ & $34.38 \pm 0.17^{\mathrm{abc}}$ & $38.0 \pm 22.3^{f}$ \\
\hline $\mathrm{Bv}-\mathrm{W}-6$ & $396.3 \pm 72.4^{\mathrm{abc}}$ & $82.65 \pm 1.51^{\mathrm{bcd}}$ & $34.75 \pm 2.18^{\mathrm{ab}}$ & $81.98 \pm 0.60^{\mathrm{abcd}}$ \\
\hline Bv-EtOH-7 & $328.1 \pm 81.4^{\mathrm{abcd}}$ & $77.54 \pm 0.77^{\text {cdefg }}$ & $27.26 \pm 0.19^{\text {cde }}$ & $36.51 \pm 9.21^{\mathrm{f}}$ \\
\hline $\mathrm{Bv}-\mathrm{W}-7$ & $232.4 \pm 44.6^{\mathrm{abcd}}$ & $72.73 \pm 2.38^{\text {fghr }}$ & $40.44 \pm 1.99^{\mathrm{a}}$ & $76.54 \pm 0.41^{\text {abcde }}$ \\
\hline $\mathrm{Bv}-\mathrm{EtOH}-8$ & $334.7 \pm 61.9^{\mathrm{abcd}}$ & $84.87 \pm 0.52^{\mathrm{abc}}$ & $26.24 \pm 0.19^{\mathrm{e}}$ & $33.06 \pm 11.17^{\mathrm{f}}$ \\
\hline $\mathrm{Bv}-\mathrm{W}-8$ & $148.0 \pm 30.3^{\mathrm{d}}$ & $75.21 \pm 2.16^{\text {defgh }}$ & $27.16 \pm 2.44^{\mathrm{de}}$ & $86.57 \pm 4.85^{\mathrm{ab}}$ \\
\hline Bc-EtOH-9 & $189.4 \pm 37.3^{\mathrm{cd}}$ & $67.78 \pm 1.11^{\mathrm{hij}}$ & $15.98 \pm 0.21^{\mathrm{g}}$ & $76.28 \pm 1.46^{\text {abcde }}$ \\
\hline Bc-W-9 & $191.0 \pm 37.6^{\mathrm{cd}}$ & $77.69 \pm 1.94^{\text {cdefg }}$ & $13.60 \pm 2.90^{\mathrm{g}}$ & $92.85 \pm 0.03^{\mathrm{a}}$ \\
\hline Bc-EtOH-10 & $247.0 \pm 47.1^{\mathrm{abcd}}$ & $82.91 \pm 0.58^{\mathrm{bcd}}$ & $19.04 \pm 0.21^{\mathrm{fg}}$ & $75.10 \pm 3.72^{\text {abcde }}$ \\
\hline $\mathrm{Bc}-\mathrm{W}-10$ & $211.3 \pm 41.0^{\mathrm{bcd}}$ & $66.78 \pm 4.23^{1 j}$ & $17.30 \pm 2.77^{\mathrm{g}}$ & $91.35 \pm 1.13^{\mathrm{ab}}$ \\
\hline Bc-EtOH-11 & $170.7 \pm 34.1^{\mathrm{cd}}$ & $83.40 \pm 0.57^{b c}$ & $11.92 \pm 0.22^{\mathrm{g}}$ & $48.14 \pm 5.40^{\mathrm{def}}$ \\
\hline $\mathrm{Bc}-\mathrm{W}-11$ & $202.4 \pm 39.5^{\mathrm{cd}}$ & $62.83 \pm 3.25^{j}$ & $18.72 \pm 2.73^{\mathrm{fg}}$ & $91.21 \pm 1.08^{\mathrm{ab}}$ \\
\hline
\end{tabular}

*Different superscript letters show the differences between the samples within each row $(p<0.05$ significance level).

TABLE 4: Phenolic component concentrations of alcohol and water extracts.

\begin{tabular}{|c|c|c|c|c|c|c|c|}
\hline Extracts & $\begin{array}{l}\text { Gallic acid } \\
\quad(\mathrm{ppm})\end{array}$ & $\begin{array}{l}\text { Chlorogenic acid } \\
\qquad(\mathrm{ppm})\end{array}$ & $\begin{array}{l}\text { Vanillic acid } \\
\text { (ppm) }\end{array}$ & $\begin{array}{l}\text { Caffeic acid } \\
\quad(\mathrm{ppm})\end{array}$ & $\begin{array}{l}\text { Syringic acid } \\
\quad(\mathrm{ppm})\end{array}$ & $\begin{array}{c}\text { trans- } \\
\text { Ferulic } \\
\text { acid (ppm) }\end{array}$ & $\begin{array}{c}\text { Sinapic } \\
\text { acid } \\
(\mathrm{ppm})\end{array}$ \\
\hline Bv-EtOH-1 & 330.407 & 1990.482 & 3.599 & 79.235 & 450.493 & - & 187.628 \\
\hline $\mathrm{Bv}-\mathrm{W}-1$ & 248.962 & 1457.368 & 7.519 & 83.052 & 167.997 & - & 147.936 \\
\hline Bv-EtOH-2 & 270.764 & 2147.935 & 39.599 & 62.666 & 867.850 & - & 221.869 \\
\hline $\mathrm{Bv}-\mathrm{W}-2$ & 70.612 & 1527.302 & 7.649 & 57.785 & 161.276 & - & 138.455 \\
\hline Bv-EtOH-3 & 301.783 & 1820.423 & 3.308 & 61.259 & 429.763 & - & 153.159 \\
\hline $\mathrm{Bv}-\mathrm{W}-3$ & 76.907 & 1838.733 & 7.688 & 73.575 & 159.643 & - & 136.127 \\
\hline Bv-EtOH-4 & 330.031 & 1746.525 & 55.326 & 125.701 & 498.830 & 37.616 & 137.746 \\
\hline Bv-W-4 & 71.751 & 1938.942 & 60.915 & 83.891 & 133.377 & - & 207.935 \\
\hline Bv-EtOH-5 & 173.777 & 1619.128 & 52.789 & 134.749 & 559.397 & 26.400 & 149.360 \\
\hline $\mathrm{Bv}-\mathrm{W}-5$ & 242.706 & 1459.171 & 23.640 & 115.551 & 180.529 & 0.145 & 142.547 \\
\hline Bv-EtOH-6 & 299.670 & 1723.521 & 39.585 & 129.781 & 541.082 & 38.894 & 138.978 \\
\hline Bv-W-6 & 71.155 & 1510.845 & 28.114 & 121.391 & 189.415 & 8.881 & 143.345 \\
\hline Bv-EtOH-7 & 308.482 & 1678.213 & 4.657 & 79.176 & - & 3.140 & 146.024 \\
\hline $\mathrm{Bv}-\mathrm{W}-7$ & 237.531 & 1692.855 & 48.325 & 152.225 & 168.403 & 13.022 & 146.292 \\
\hline Bv-EtOH-8 & 507.050 & 1773.266 & 4.123 & 90.684 & 549.545 & - & 137.539 \\
\hline $\mathrm{Bv}-\mathrm{W}-8$ & 76.685 & 1357.626 & 6.049 & 78.679 & 177.098 & - & 139.624 \\
\hline Bc-EtOH-9 & 285.826 & 466.083 & 23.110 & 76.845 & 538.558 & 0.232 & 136.504 \\
\hline Bc-W-9 & 138.940 & 225.764 & 46.429 & 80.466 & 326.977 & 19.473 & 148.021 \\
\hline $\begin{array}{l}\text { Bc-EtOH- } \\
10\end{array}$ & 275.804 & 869.295 & 68.742 & 77.577 & 472.667 & 30.090 & 142.288 \\
\hline $\mathrm{Bc}-\mathrm{W}-10$ & 200.513 & 767.036 & 4.007 & 68.073 & 204.618 & 14.682 & 137.678 \\
\hline $\begin{array}{l}\mathrm{Bc}-\mathrm{EtOH}- \\
11\end{array}$ & 218.348 & 446.648 & 52.048 & 67.934 & 549.820 & 7.841 & 148.370 \\
\hline Bc-W-11 & 41.186 & 79.109 & 3.951 & 34.677 & 13.634 & - & 136.605 \\
\hline
\end{tabular}

syringic acid, $p$-coumaric acid, trans-ferulic acid, and sinapic acid were determined (Table 4). Similar to the antioxidant activity tests, the level of phenolic compounds in ethanol extracts of the fruit samples was higher compared to the water extracts. Chlorogenic acid and syringic acid have been found to be the most abundant phenolic compounds in Berberis fruit extracts. The presence of 4-hydroxybenzoic acid and $p$-coumaric acid could not be observed in the fruit extracts investigated. High concentrations of chlorogenic acid, syringic acid, gallic acid, sinapic acid, caffeic acid, 
TABle 5: Antimicrobial activities of Berberis fruit extracts against foodborne pathogens.

\begin{tabular}{|c|c|c|c|c|c|}
\hline Extracts & Escherichia coli & Bacillus cereus & Salmonella typhimurium & Yersinia enterocolitica & Staphylococcus aureus \\
\hline BvW1 & - & - & - & - & - \\
\hline $\mathrm{Bv}-\mathrm{W}-2$ & - & - & - & - & - \\
\hline $\mathrm{Bv}-\mathrm{W}-3$ & - & - & - & - & - \\
\hline Bv-W-4 & - & + & ++ & + & ++ \\
\hline $\mathrm{Bv}-\mathrm{W}-5$ & - & - & - & - & - \\
\hline $\mathrm{Bv}-\mathrm{W}-6$ & - & - & - & - & - \\
\hline $\mathrm{Bv}-\mathrm{W}-7$ & - & - & - & - & - \\
\hline $\mathrm{Bv}-\mathrm{W}-8$ & - & - & - & - & - \\
\hline $\mathrm{Bc}-\mathrm{W}-9$ & - & - & + & + & ++ \\
\hline $\mathrm{Bc}-\mathrm{W}-10$ & - & - & - & - & + \\
\hline $\mathrm{Bc}-\mathrm{W}-11$ & - & - & + & + & ++ \\
\hline
\end{tabular}

The symbols + and ++ reveal the zone of inhibition as $1-7 \mathrm{~mm}$ and $8-15 \mathrm{~mm}$ diameter, respectively.

vanillic acid, and trans-ferulic acid were observed (Table 4). It has been determined that syringic acid has high-level antioxidant activity [29]. Previously, Gündoğdu [17] determined chlorogenic acid as the dominant phenolic compound in B. vulgaris fruits which was similar to our findings. Gholizadeh-Moghadam et al. [28] reported that in the extracts of Berberis fruits, gallic acid and $p$-coumaric acid were the most commonly found phenolic compounds and the phenolic compounds and their levels were reported to be gallic acid $\left(334.82 \mathrm{mg} \cdot \mathrm{L}^{-1}\right)$, caffeic acid $\left(51.78 \mathrm{mg} \cdot \mathrm{L}^{-1}\right)$, chlorogenic acid $\left(119.53 \mathrm{mg} \cdot \mathrm{L}^{-1}\right), \quad p$-coumaric acid $\left(257.09 \mathrm{mg} \cdot \mathrm{L}^{-1}\right)$, cinnamic acid $(0.57 \mathrm{mg} / \mathrm{L})$, rutin $(7.61 \mathrm{mg} /$ $\mathrm{L})$, apigenin $(4.44 \mathrm{mg} / \mathrm{L})$, and quercetin $(37.20 \mathrm{mg} / \mathrm{L})$ as the highest concentrations in the aforementioned study. Variability in the content of phenolic compounds and flavonoid concentrations in plant species may be related to genetic structure, environmental conditions (light, temperature, soil conditions, humidity, and fertilizer), harvest time, and storage conditions [29-31]. Overall, our findings revealed the rich phenolic content of the Berberis fruits.

3.4. Antimicrobial Activity. There is an increasing trend to find new sources of antimicrobials and in this study, the water extracts of Berberis fruits were tested against five foodborne pathogenic bacteria. The antimicrobial activity was extract specific as only four extracts showed antimicrobial activity. Extract Bv-W-4 showed the highest level of antimicrobial activity observed against four pathogenic bacteria except $E$. coli in which none of the extracts showed antimicrobial activity (Table 5). Extract $\mathrm{Bv}-\mathrm{W}-4$ was more effective to $S$. typhimurium and $S$. aureus then $Y$. enterocolitica and B. cereus and to the latter pathogenic strain, only extract $\mathrm{Bv}-\mathrm{W}-4$ showed antimicrobial activity. Importantly, the only extract that showed antimicrobial activity to pathogenic bacteria from B. vulgaris was Bv-W-4 and the other three extracts that showed antimicrobial activity were from B. crataegina.

In this study, fruit extracts of B. vulgaris and B. crataegina were found to show antimicrobial activity against $B$. cereus, S. typhimurium, Y. enterocolitica, and S. aureus. Previously, Awan et al. [32] investigated the antimicrobial activity of Berberis calliobotrys, Berberis orthobotrys, and Berberis psedumbellata fruits and found that they showed antimicrobial activity against E. coli, Pseudomonas spp., and Bacillus cereus bacterial strains. Similar to this study, our finding also reveals the potential of the extracts of Berberis fruits as antimicrobials to be used for different purposes.

\section{Conclusion}

In this study, wild B. vulgaris and B. crataegina were collected from Bayburt province and their physicochemical characteristics, phenolic content, and antioxidant and antimicrobial properties were determined. The physicochemical characteristics of the Berberis fruits were affected by the collection location, suggesting the role of geographical conditions. The total phenolic content of the samples was observed to be within the range of 148.0-448.3 $\mu \mathrm{g} \cdot \mathrm{GAE} \cdot \mathrm{mg} \cdot \mathrm{DM}^{-1}$. Both ethanol and water extracts of the fruits showed higher level of antioxidant activity tested by $\beta$-carotene, $\mathrm{DPPH}^{\bullet}$, and $\mathrm{ABTS}^{\bullet+}$ tests and the ethanol extracts showed higher level of antioxidant activity compared to the water extract. The phenolic profile of the Berberis fruits was determined by HPLC analysis, and chlorogenic acid and syringic acid were found to be the most abundant phenolic compounds in Berberis fruits. The antimicrobial activity of the water extracts of the Berberis fruits were tested against foodborne pathogens, and three extracts showed antimicrobial activity against three pathogenic bacteria. In summary, wild barberry $B$. vulgaris and B. crataegina have important potential for food industry and for other technological purposes as antioxidant compounds.

\section{Data Availability}

The data used to support the findings of this study are available from the corresponding author upon request.

\section{Conflicts of Interest}

The authors declare that there are no conflicts of interest regarding the publication of this paper.

\section{Acknowledgments}

This research was supported by Bayburt University through an internal grant. 


\section{References}

[1] H. V. Kuhlein, "Nutrient values in indigenous wild berries used by the Nuxalk people of Bella Coola British Columbia," Journal of Food Composition and Analysis, vol. 2, no. 1, pp. 28-36, 1989.

[2] O. Kamiloglu, S. Ercisli, M. Sengül, C. Toplu, and S. Serce, "Total phenolics and antioxidant activity of jujube (Zizyphus jujube Mill.) genotypes selected from Turkey," African Journal of Biotechnology, vol. 8, no. 2, pp. 303-307, 2009.

[3] M. J. M. Christenhusz and J. W. Byng, "The number of known plants species in the world and its annual increase," Phytotaxa, vol. 261, no. 3, pp. 201-217, 2016.

[4] T. Khan, I. A. Khan, and A. Rehman, "Evaluation and detailing of taxonomic and historical perspectives on genus Berberis from Pakistan," Journal of Environment and BioSciences, vol. 6, no. 4, pp. 361-367, 2015.

[5] Ü. Akkemik, Türkiye’nin Doğal-Egzotik Ağaç ve Çalilari, Orman ve Su İşleri Bakanlığı Orman Genel Müdürlüğü, Istanbul, Turkey, 2018.

[6] M. Rahimi-Madiseh, Z. Lorigoini, H. Zamani-Gharaghoshi, and M. Rafieian-Kopei, "Berberis vulgaris: specifications and traditional uses," Iranian Journal of Basic Medical Sciences, vol. 20, no. 5, pp. 569-587, 2017.

[7] M. Özgen, O. Saraçoğlu, and E. N. Geçer, "Antioxidant capacity and chemical properties of selected barberry (Berberis vulgaris L.) fruits," Horticulture, Environment, and Biotechnology, vol. 53, no. 6, pp. 447-451, 2012.

[8] M. Fatehi, T. M. Saleh, Z. Fatehi-Hassanabad, K. Farrokhfal, M. Jafarzadeh, and S. Davodi, "A pharmacological study on Berberis vulgaris fruit extract," Journal of Ethnopharmacology, vol. 102, no. 1, pp. 46-52, 2005.

[9] Z. Fatehi-Hassanabad, M. Jafarzadeh, A. Tarhini, and M. Fatehi, "The antihypertensive and vasodilator effects of aqueous extract from Berberis vulgaris fruit on hypertensive rats," Phytotherapy Research, vol. 19, no. 3, pp. 222-225, 2005.

[10] F. Gedikli, "Investigation of wallnut (Juglans regia), black mulberry (Morus nigra), barberry (Berberis crataegina), madder (Rubia tinctorum) and alder (Alnus glutonisa) as a protein dye in polyacrylamide gel electrophoresis," M.S. thesis, Gaziosmanpaşa University, Tokat, Turkey, 2006.

[11] S. Toroğlu and M. Çenet, "The methods used to determine antimicrobial activity of the plants and their application area," KSIU Journal of Engineering Sciences, vol. 9, no. 2, pp. 12-20, 2006.

[12] J. Meng, Y. Fang, A. Zhang et al., "Phenolic content and antioxidant capacity of Chinese raisins produced in Xinjiang province," Food Research International, vol. 44, no. 9, pp. 2830-2836, 2011.

[13] M. Ciniviz and H. Yildiz, "Determination of phenolic acid profiles by HPLC in lacto-fermented fruits and vegetables (pickle): effect of pulp and juice portions," Journal of Food Processing and Preservation, 2020.

[14] İ. Gülçin, "The antioxidant and radical scavenging activities of black pepper (Piper nigrum) seeds," International Journal of Food Sciences and Nutrition, vol. 56, no. 7, pp. 491-499, 2005.

[15] D. Huang, B. Ou, and R. L. Prior, "The chemistry behind antioxidant capacity assays," Journal of Agricultural and Food Chemistry, vol. 53, no. 6, pp. 1841-1856, 2005.

[16] İ. Gülçin, M. Oktay, Ö. İ. Küfrevioğlu, and A. Aslan, "Determination of antioxidant activity of lichen Cetraria islandica (L) ach," Journal of Ethnopharmacology, vol. 79, no. 3, pp. 325-329, 2002.
[17] M. Gündoğdu, "Determination of antioxidant capacities and biochemical compounds of Berberis vulgaris L. fruits," Advances in Environmental Biology, vol. 7, no. 2, pp. 344-348, 2013.

[18] E. B. Akin, I. Karabulut, and A. Topcu, "Some compositional properties of main Malatya apricot (Prunus armeniaca L.) varieties," Food Chemistry, vol. 107, no. 2, pp. 939-948, 2008.

[19] H. Demir, "Chemical composition of some wild (Polygonum cognatum, Tragopoxgom reticulatus and Berberis vulgaris) plants collected from Erzurum," Bahçe, vol. 35, no. 1-2, pp. 55-60, 2006.

[20] A. Karabulut, "Biochemical characterization of Berberis vulgaris L. and Berberis crataegina DC. wild fruits exist naturally in Bayburt city," M.S. thesis, Bayburt University, Bayburt, Turkey, 2018.

[21] M. Akbulut, S. Çalişir, T. Marakoğlu, and H. Çoklar, "Some physicomechanical and nutritional properties of barberry (Berberis vulgaris L.) fruits," Journal of Food Process Engineering, vol. 32, no. 4, pp. 497-511, 2009.

[22] H. Yildiz, S. Ercisli, M. Sengul et al., "Some physicochemical characteristics, bioactive content and antioxidant characteristics of non-sprayed barberry (Berberis vulgaris L.) fruits from Turkey," Erwerbs-Obstbau, vol. 56, no. 4, pp. 123-129, 2014.

[23] M. Ahmed, M. A. Anjum, R. M. M. Naz, M. R. Khan, and S. Hussain, "Characterization of indigenous barberry germplasm in Pakistan: variability in morphological characteristics and nutritional composition," Fruits, vol. 68, no. 5, pp. 409422, 2013.

[24] S. B. Ardestani, M. A. Sahari, M. Barzegar, and S. Abbasi, "Some physicochemical properties of Iranian native barberry fruits (abi and poloei): Berberis integerrima and Berberis vulgaris," Journal of Food and Pharmaceutical Sciences, vol. 1, pp. 60-67, 2013.

[25] V. Okatan and A. M. Çolak, "Chemical and phytochemicals content of barberry (Berberis vulgaris 1.) fruit genotypes from Sivaslı district of Uşak province of western Turkey," Pakistan Journal of Botany, vol. 51, no. 1, pp. 1-6, 2018.

[26] N. Ersoy, M. Kupe, H. I. Sagbas, and S. Ercisli, "Physicochemical diversity among barberry (Berberis vulgaris L.) fruits from eastern Anatolia," Notulae Botanicae Horti Agrobotanici Cluj-Napoca, vol. 46, no. 2, pp. 336-342, 2018.

[27] G. Motalleb, P. S. Hanachi, H. Kua, F. Othman, and R. Asmah, "Evaluation of phenolic content and total antioxidant activity in Berberis vulgaris fruit extract," Journal of Biological Sciences, vol. 5, no. 5, pp. 648-653, 2005.

[28] N. Gholizadeh-Moghadam, B. Hosseini, and A. Alirezalu, "Classification of barberry genotypes by multivariate analysis of biochemical constituents and HPLC profiles," Phytochem Analysis, vol. 30, no. 4, pp. 385-394, 2019.

[29] A. A. Mariod, R. M. Ibrahim, M. Ismail, and N. Ismail, "Antioxidant activities of phenolic rich fractions (PRFs) obtained from black mahlab (Monechma ciliatum) and white mahlab (Prunus mahaleb) seedcakes," Food Chemistry, vol. 118, no. 1, pp. 120-127, 2010.

[30] R. L. Prior, G. Cao, A. Martin et al., "Antioxidant capacity as influenced by total phenolic and anthocyanin content, maturity, and variety of Vaccinium species," Journal of Agricultural and Food Chemistry, vol. 46, no. 7, pp. 2686-2693, 1998.

[31] P. Ninfali and M. Bacchiocca, "Polyphenols and antioxidant capacity of vegetables under fresh and frozen conditions," Journal of Agricultural and Food Chemistry, vol. 51, no. 8, pp. 2222-2226, 2003. 
[32] M. S. Awan, S. Ali, A. Ali, A. Hussain, and M. A. Qazalbash, "A comparative study of barberry fruits in terms of its nutritive and medicinal contents from CKNP region, GilgitBaltistan, Pakistan," Journal of Biodiversity and Environmental Sciences, vol. 5, no. 2, pp. 9-17, 2014. 